\title{
ADAM BULAWA* \\ WNHiS UKSW, Warszawa \\ THEORY AND PRACTICE. VERIFYING THE COMMAND SKILLS OF THE GRADUATES OF POLISH MILITARY SCHOOL IN GENOA AND CUNEO (1861-1862) DURING THE JANUARY UPRISING (1863-1864)
}

On the 10th on March 2012, in the Piedmontese town of Cuneo, on the facade of the building of former St. Francis Collegium a commemorative plaque memorializing the operations of Polish Military School, established in 1861 in Genoa and later in 1862 moved to the subalpine town, was ceremonially revealed. Speeches were given by mayor of Cuneo, Alberto Valmaggia, papal nuncio in Poland who was born in Cuneo, archbishop Celestino Migliore, ambassador of RP in Vatican, Hanna Suchocka, General Consul of RP in Milan, Krzysztof Strzałka, and secretary of Council for the Protection of Struggle and Martyrdom Sites (funder of the plaque), Andrzej Krzysztof Kunert ${ }^{1}$. Translated to Polish language the plaque reads [th - this translation provides the English rendition of the text on the plaque]

Since 26th of April till 30th of July 1862

THE HALLS OF ST. FRANCIS COLLEGIUM ACCOMMODATED MIGRANTS FROM POLISH MILITARY SCHOOL CUNEO WELCOMED THEM NOBLY AND BROTHERLY REMEMBERING POLES FIGHTING ALONGSIDE ITALIANS FOR THE LIBERATION AND UNIFICATION OF ITALY

IN THE 150TH ANNIVERSARY OF UNIFICATION RESIDENTS AND POLES REMEMBER

AD 2012

Because Genoa-Cuneo Polish Military School is frequently mentioned as one of the forges of the commanding staff of the Polish national uprising it is prudent to closely analyze how the theoretical knowledge acquired therein was applied in actual military operations. The examination of the career of several of the graduates of the migratory institution will enable us to answer the question of how its alumni compared to other provenance cadres such as former officers from the armies of the partitioners, veterans of the 1830-1831 uprising, participants of the 1831-1863 revolutionary and liberation fights or civilians.

\footnotetext{
* Translated by Spektra Sp. z o.o.

1 Website of Council for the Protection of Struggle and Martyrdom Sites, 10.03.2012.
} 


\section{About the school}

During the late Fall of 1861 the Parisian Association of Polish Youth, iintending to incite an armed uprising in the lands of the Russian partition decided to provide the insurgency with a trained officer cadre recruited from the representatives of Polish youths staying in exile and regularly supported from the country. Possible Supreme Commander of the fight for liberation, the idol of the adolescent patriots, general Ludwik Mierosławski was supposed to take the leadership of the Polish Military School which was supposed to be established in Italy ${ }^{2}$ due to the reluctance of the authorities of Second French Empire. Polish-Italian Turin Committee (Camitato di sussidio agli esuli Polacchci) established in 1861 and the personal intervention of Giuseppe Garibaldi contributed to the acquisition of permission of the authorities of Kingdom of Italy to establish PMS in a two-storey brick-built building called Casa Bianchetti and located in Genoa (circa IX/1 X 1861). The School Supervising Committee included such personas as general fr. Napoleon Hieronim Bonaparte, General Hieronim Bixio, dr Ignazio Occhipinti, fr. Marceli Lubomirski and Deputy Lorenzo Valerio ${ }^{3}$. The authorities donated 100,000 francs for the renovation, adaptation and basic furnishings and equipment. Tadeusz Kościuszko, hero of two continents, procured for the institution a drill area, rifles, steeds, canons, 100 red shirts and as much blankets ${ }^{4}$. Patriotically disposed youths were garrisoned rather rapidly and inducted into the military discipline and later clothed in light gray coats and red four-cornered cap lined with fleece ${ }^{5}$.

Several months-long training was supposed to enable cadets to master the art of commanding a battalion in combat and the basics of instructor's knowledge cadets could further use to train Polish legions or insurrectionist armed forces. The school had a rather extensive and well prepared teaching staff 6 . The school also took care of the moral and patriotic upbringing of cadets who were required to remain faithful to the national cause and social justice. This upbringing was greatly helped by the adoption of the so called Agreement

\footnotetext{
Księga Pamiątkowa 1830-29 XI-1930. Szkice z dziejów szkół piechoty polskiej, Ostrów-Komorowo 1930, pp. 212-230; A. Knot, Dzieje szkolnictwa wojskowego w Polsce, Lwów 1938, pp. 98-102; E. Halicz, Polska Szkoła Wojskowa w Genui i Cuneo (1861-1862), „Biuletyn Wojskowej Akademii Politycznej”, Seria Historyczna no. 2, year V, no. 3 (16), Warszawa 1959, pp. 110-128; W.Karbowski, Polska Szkoła Wojskowa we Włoszech (18611862), „Studia i Ma-teriały do Historii Wojskowosci”, vol.VIII, part 2, Warszawa 1962, p.21 in; J.Moliński, Przygotowania do wybuchu po-wstania styczniowego, ,SiMdHW”, vol.VIII, part 2, pp.95-97; J. Cytowski, Z dziejów polskiego szkolnictwa wojskowego (Polskie szkoły i kursy wojskowe w latach 1832-1918), „Zeszyty Naukowe WAP”, no. 4 (137), Warszawa 1988, pp.171-174; A. Cwer, Polska wojskowa myśl wychowawcza w latach 1794-1864, Kielce 2010, pp.205-210.

3 J. Białynia-Chołodecki, Polska Szkoła Wojskowa. Księga Pamiątkowa w 40 rocznicę powstania 1863-4, Lwów 1904, p.19; Zagłoba, Polska Szkoła Wojskowa we Włoszech, „Polska Zbrojna” no. 23 of 24 I 1923; K.Morawski, Polacy i sprawa polska w dziejach Italii w latach 1830-1866, Rozprawy historyczne Towarzystwa Naukowego Warszawskiego, vol. XVIII, coll. 1, Warszawa 1937, p.156; J. Chodynicki, Szkoła w Cuneo, „Ateneum Wileńskie”, 1928, no.5, p.193; E. Halicz, Polska Szkoła Wojskowa, p.115; W. Mazurkiewicz, Emigracja polska w 1862 r. Szkoła Genu-eńska. Zjednoczenie, Paryż 1862, pp.122-123; Zeznanie Władysława Daniłowskiego przed carską komisją śledczą w: Zeznania sledcze o powstaniu styczniowym, Wrocław 1956, p. 98.

4 Z pamiętnika Romana Rogińskiego 1859-1863, Kraków 1898, p.17; A. Lewak, Polska korespondencja Józefa Garibaldiego, Kraków 1932, p.65.

5 A.Lewak, Czasy Wielkiej Emigracji, Warszawa 1930, p. 304; A. Knot, Dzieje szkolnictwa wojskowego w Polsce, p. 99; W. Karbowski, Polska Szkoła Wojskowa, p. 28.

6 A. Knot, Dzieje szkolnictwa wojskowego, p. 56; E.Halicz, Polska Szkoła Wojskowa, p. 115; W. Karbowski, Polska Szkoła Wojskowa, p. 28, 55.
} 
binding cadets and instructors of the Polish Military School in Italy ${ }^{7}$, establishing a student council referred to as Youth Association and a press organ „Głos z Paryża i Genui [tn - Voice from Paris and Genoa]".

After the internal turning point general Józef Wysocki replaced Mierosławski in the capacity of the headmaster (27th of March 1862), colonel Aleksander Fijałkowski, commander of the Polish legions in Italy in 1849, was appointed to the position of direct commander and colonel Aleksander Waligórski ${ }^{8}$ was installed as the director of sciences. The syllabus of the school consisting of infantry, cavalry and artillery departments included the following subjects and classes: theory and practice of infantry and cavalry drill, theory and practice of artillery operations, manufacturing gunpowder and munitions, scattered battle order and „kosynierzy” [tn - scythers, scythe wielding infantry] formations drill; mathematics, strategy, tactics and history of armed conflicts, field fortifications, military geography and cartography of Polish territories, geometry and pyrotechnics. Physical education, gymnastics and sport activities were also included. There was also a library containing manuals, handbooks, regulations and classical publications concerning the subject of military operations.

By the end of April 1862 the school began to function in the picturesque submontane town of Cuneo 9 . It was located in a formerly abandoned but spacious ${ }^{10}$ building of a PostFranciscan monastery and equipped, in accordance with Garibaldi's wishes, with 20 horses, 6 cannons and a stock of small arms. It is here were the uniforms of the cadets were changed to resemble the uniforms of Polish legionaries fighting in Hungary during the Revolution of 1848 (at that time commanded by Józef Wysocki): navy blue jackets with amaranth edging and white jackets and red four-cornered caps worn during summer. Non-commissioned officer course was to last 3 months and commissioned officer course was to last 6 months at the minimum and after conclusion of the course a cadet was expected to pass an examination before the commission board.

Circumstances favorable for the existence of school ended shortly ${ }^{11}$. The existence of an institution lacking legal grounds for operation was for the authorities of Tsarist Empire, who were pursuing the liquidation of the Polish school, a provocation and Polish Military School was considered to be a Turine's tool of diplomatic pressure used to press on Petersburg not willing to recognize young Polish state ${ }^{12}$. The cadets and graduates of the Polish school

\footnotetext{
7 E.
1862 .

E. Halicz, Polska Szkoła Wojskowa, appendix no 1, p.129-131; text in „Przeglądzie Rzeczy Polskich” no 6,

8 E. Halicz, Polska Szkoła Wojskowa, p. 122; W. Karbowski, Polska Szkoła Wojskowa, pp. 54-55; W. Mickiewicz, Pamiętniki, vol. II, Kraków 1926, pp. 205-220; Z pamiętnika Romana,pp. 25-26.

9 E. Halicz, Polska Szkoła Wojskowa., p. 123; W.Karbowski, Polska Szkoła Wojskowa, p. 56; „Przegląd Rzeczy Polskich", 16 V 1862-art. Polska szkoła wojskowa w Cuneo; Z pamiętnika Romana, pp. 28-29.

10 J. Zlasnowski, Wspomnienia ze szkoły podchorążych we Włoszech, „Tygodnik Ilustrowany”, no 4, 1917.

11 J. Chodynicki, Szkoła w Cuneo, pp.203-205; E. Halicz, Polska Szkoła Wojskowa., p.126; „Dziennik Poznański” 1862, no. 159; „Przegląd Rzeczy Polskich” 1862, no. 7; „Głos z Paryża i Genui”, 1862, no. 5 of 10 VII; compare with B.Czart., rkps 3743, k.537-538 - letters of Fryderyk Wilhelm IV to Prussian ambassador in Bologne, Franciszek Luchesini, concerning supporting Russian efforts to disband the school in Cuneo which ,educates future consipirers, subversive elements and man capable of conducting guerilla warfare on the lands of our friends, Russians" 14 V i 22 V 1862; W. Mickiewicz, Emigracja polska 1860-1890, Kraków 1908, pp.18-19.

12 W. Karbowski, Polska Szkoła Wojskowa, p. 22, 28; See ana rticle in „Dziennikk Poznański” 1862, no. 159; „Przegląd Rzeczy Polskich” 1862 no. 6 and no. 7; „Głos Paryża i Genui” 1861 no. 2 of 29 XI; Materiaty po śp. Władysławie Milowiczu, Wydawnictwo materiałów do historii powstania 1863-1864, Lwów 1888, vol. IV, p.48.
} 
were considered to be possible agents who will be used to incite insurrectionist uprisings. The diplomatic efforts oriented towards liquidation of similar institutions in the Western Europe, due to the interference in the home affairs of France, England and Italy, exemplified by requests and diplomatic pressure, were called a delicate matter. The popularity of the institution in country and abroad was perceived as a disparagement for the prestige of Tsarist Empire and inspired nationalist movements in the country to stoke up insurrectionist sentiments ${ }^{13}$. Due to the political pressure exerted by ambassadors of Russia and Prussia king Wiktor Emanuel commanded prime minister Urban Ratazzi to suspend and later disband the school (on the 26th of June). By the end of July 1862 Poles vacated the town.

It is prudent to cite the works of three participants of the national insurrection and the authors of texts concerning the subject of January uprising relating to the students of the migratory cadet school ${ }^{14}$. Agaton Giller, representing mild, centre-oriented views, wrote: Our Youth in their short time at the school, more interested in intrigues, divisions and arguments than in learning, (...) came to be arrogant, weird and pretentious. Many thought that they have acquired enough qualifications to become the leader of the uprising and therefore wished not to serve the cause but to command. They expressed (...) anarchic disposition under the influence of old migrant pamphlets, distrust of the age and experience, disregard of achievements, impatience and insolence of the initiative most foolhardy and lack of responsibility and remorse for the defeats they were sure to experience due to their lack of skills and ample pride. Conservative author Walery Przyborowski concluded: They pushed for a rapid, instantaneous insurrection, they devised most foolhardy designs they were never able to put to work and not skillful enough to complete. Apart from several more lucid individuals who at least knew how to die heroically the rest of them were most reckless and incapable people. In contrast, the „red” Władysław Milowicz claimed, that: All of them actively participated in the uprising and rendered great services and many of them later became one of the bravest commanders in the uprising (...). What was the truth? The analysis of the particular examples should help us to answer this question.

\section{The attempt at assessment of the commanders trained in the Polish Military School in Italy}

Taking into account the following criteria: the size of a unit (at least 100 subordinates) and the independence of the command (participation in at least 1 combat engagement) we were able to establish that from 237 selected insurrectionist commanders from the 1863-1864 period 15 were the graduates of Polish Military School in Italy ${ }^{15}$ : Wacław Karol Broniewski,

13 W. Przyborowski, Historia dwóch lat 1861-1862, vol. V, Kraków 1892, p. 253; Z papierów po śp. Władysławie Milowiczu, Wydawnictwo materiałów, vol. IV, p. 49; „Przegląd Rzeczy Polskich” 1862, 30 VI; „Głos z Paryża i Genui”, 1862, no 5 z 10 VII; ,Dziennik Poznański” 1862, no 137 z 17 V.

14 A. Giller, Historia powstania narodu polskiego w latach 1861-1864, Paryż 1868; vol. II, p. 313; W. Przyborowski, Historia, vol. V, p. 255; Z papierów po śp. W.Milowiczu, vol. IV, p. 49; Ci z Genui w powstaniu, „Dziennik Poznański” 1863, no ; Szkoła Polska w Genui i Cuneo, „Rzeczypospolita” 1913 no 108.

15 The register of the alumni of Polish Military School supplemented by Aleksander Zdanowski lists surnames (in: J.Białynia-Chołodecki, Księga pamiątkowa -w 40 rocznicę powstania 1863-1864, Lwów 1904, pp. 20-23; A. Sujkowski, Emigracja i powstanie styczniowe (1862-1865) - in: Księga Pamiatkowa Szkoły Podchorażych Piechoty, Ostrów Mazowiecka 1930, pp. 222-223, W. Karbowski, Polska Szkoła Wojskowa we Włoszech, pp. 72-77 - supplement of the anonymous work Szkoła Wojskowa Polska w Genui i Cuneo, ,Rzeczpospolita” no. 108 z 1913 , p. 260 i A. Sujkowski, op.cit). 
Teodor Cieszkowski, Leopold Czapiński, Faustyn Gryliński, Władysław Jabłonowski, Teofil Jurkowski, Bolesław Kołyszko, Aleksander Littich, Anastazy Mossakowski, Józef Oksiński, Roman Rogiński, Robert Skowroński, Paweł Suzin, Józef Tłuchowski i Feliks Wysłouch

\section{Elite commanders}

Roman Rogiński is one of the finest alumni of the Genoa-Cuneo institution. The plan to raid the poviat garrison in Biała in the Podlasie region on the January Night he prepared confirms the supreme assessment Rogiński received from the insurrection authorities though this evaluation was never confirmed with a promotion to an appropriate military rank. The determination of Rogiński to partake in action is evidenced by him, alongside with 80 volunteers, entering Biała. However, in the face of the enemy's numerical superiority (approx. 600 soldiers under the command of major-general Mamajew consisting of a cavalry artillery battery, a unit of infantry, a sotnia [tn - a 100-men strong unit] of Cossacks and a unit of non-combat support personnel) and low morale of the local conspirators he left the town after a brief clash with the Cossack unit ${ }^{16}$. Within the next days the young commander of the Bialski region displayed organizational skills and maturity by organizing an insurrectionist regiment armed with basic weaponry. The first major battle (1st of February 1863, Białka) was an excellent display of his command skills ${ }^{17}$. After scouting the area and analyzing the enemy forces (approx. 1000 insurrectionists were facing a battalion of the Pskowski infantry regiment, 2 riflemen units of Rewelski infantry regiment, 15 Cossacks and a technical unit, approx. 1300 tired and confused, but better equipped and trained Russians in total) he, with a help of an experienced Chief of Staff, made a decision to conduct a night attack on the enemy camp. He utilized element of diversion in an attempt to cut off enemies from the reserve forces and defeat them. In the face of the „kosynier” unit failure to engage artillery units he skillfully used cavalry reserves to prevent insurrectionist forces from routing and gave a command for an orderly retreat. Crossing the Bug river after leaving the capital of poviat and retreating from the forces of lieutenant colonel Wimberg (400 infantrymen, 50 Cossacks, 1 cannon, 4th of February, Niemirów by the Bug river) in the early stages of the insurrection was an example of a well executed marching column maneouvre ${ }^{18}$.

16 S. Gesket, Voennyje dejstvija w Carstve Polskim v 1863 godu. Nacalo vozstanija (I-1 poł.III), ed. A. Puzyrewski, Varsava 1894, pp. 153-154; W. Przyborowski, Dzieje 1863 r., vol. I, Kraków 1897, p. 94; S. Zieliński, Bitwy i potyczki 1863-1864, Rapperswil 1913, p. 56; S. Płoski, Działania Rogińskiego w powstaniu styczniowym, „Przegląd Hi-storyczno-Wojskowy”, 1938, vol.X, no.1, pp.1-28; J. Tomczyk, Organizacja cywilno-wojskowa powstania styczniowego w Lubelskiem i na Podlasiu, „Roczniki Lubelskie”, vol. 6:1963, p. 38; S. Góra, Partyzantka na Podlasiu 1863-1864, Warszawa 1976, pp. 55-56; „Wiadomosci z pola bitwy”, 1863 no.; „Czas” 1863 no. 29; „Dziennik Powszechny" 1863, no 20; W. Lewandowski, Pamiętniki, p.; R. Rogiński, Zeznania w: Idem, Zeznania $i$ wspomnienia, opr. S. Kieniewicz, Warszawa 1983, pp. 49-50.

17 W. Przyborowski, Dzieje 1863 r., vol. I, p.171; S. Zieliński, Bitwy, pp. 57-58; S. Płoski, Działania Rogińskiego, pp. 11-12; S. Góra, Partyzantka na Podlasiu, pp. 75-79; Urzędowy wykaz, p. 279; „Wiadomosci z pola bitwy” 1863, no. 3; „Czas” 1863, nos. 31, 32, 37, 38, 48; „Dziennik Powszechny” 1863, no. 27, 36; „Nadwiślanin”, 1863, no. 17; R. Rogiński, Zeznania, pp. 56-58.

18 M.I. Cyłow, Sbornik raporiażenij M.N. Murawiewa po usmirieniju polskogo miatieża w Siwero-Zapdnych gubiernijach 1863-1864, Wilno 1866, p. 306; S. Gesket, Voennyje dejstvija., p. 167 i n; W. Przyborowski, Dzieje 1863 r., vol. I, p. 191;N. Berg, Zapiski o powstaniu polskim 1863 i 1864 roku i poprzedzajacej powstanie epoki demonstracji od 1856 r., Kraków 1898, vol. II, p.315; S. Zieliński, Bitwy, p.319; S. Płoski, Działania Rogińskiego, p.16; S. Góra, Partyzantka na Podlasiu, pp. 80-81; „Wiadomości z placu boju” 1863, no. 1, 3; „Czas” 1863, no. 37; „Dziennik Powszechny” 1863, no. 30; R. Rogiński, Zeznania, p. 63. 
The participation of Rogiński in the battle concluding the military initiative stage of the insurrectionists from Podlasie (7th of February, Siemiatycze ${ }^{19}$ ) indicates that he was not lacking in character traits quintessential for a commander. At the suggestion of Władysław Cichorski-Zameczek he sent over a unit of cavalry but arriving with the entirety of his forces he was unable to submit to the command of the insurrection voivode [tn - military commander] Walenty Lewandowski formally commanding the 4300-men strong battle-group and later he arrived too late to garrison the line of defense he was assigned to and, without the cooperation or consultation with his colleagues, he vacated the strategic position hastily and chaotically. The chaotically commanded units fell before the push of general Zachar Maniukin's battle-group supported by the reinforced column of colonel Krywonosow (3 rifle units of the Libawski infantry regiment, 2 units of the rifle battalion, 5th unit of the Kałużski infantry regiment and reserves, approx. 2500 soldiers in total). Thus the extraordinary tale of the diversionary raid of Rogiński's dwindling but occasionally reinforced insurrectionist forces into the lands of Belarus begun. By using scouting units and choosing proper spots for camping Rogiński escaped the pursue of general Iwan Nostitz' forces (2 units of Pskowski and Rewelski infantry regiments, Cossack sotnia - approx. 490 soldiers, 4 canons) during crossing the Leśna river (11th of February, Most Królowej) suffering only 50\% casualty rate ${ }^{20}$. With 85 subordinates Rogiński raided a town garrisoned by 250 reservist soldiers capturing arms and provisions (13th of February, Prużany) ${ }^{21}$. Further division of the „unit of daredevils” did not end the march during which the unit continued to destroy communication infrastructure. Due to the apathy of the local populace the idea to assault town of Pińsk fell flat. Miniscule, 30 -men strong unit was finally defeated by the numerical superiority of 700 soldiers from 3 units of Rewelski infantry regiment and a sotnia of captain Jewdokimow (26th of February, Borki $)^{22}$. On the 3rd of March in Turów, after 24 days of the 750-kilometres long raid into the enemy territory the daring commander of the unit was captured ${ }^{23}$.

Few months-long education in the migrant school was the only preparation Józef Oksiński, the most persistent of the insurrectionist commanders in the Kaliskie region, received.

19 W. Przyborowski, Dzieje 1863 r., vol. I, pp. 108-109; S. Zieliński, Bitwy, pp. 320-321; Miłowidow, Rasporiażenija, p. 569; S. Płoski, Działania Rogińskiego, pp. 18-19; S. Góra, Działalność powstańcza Romana Rogińskiego na Podlasiu, „Rocznik białostocki”, vol.6: 1965, p. 380; S. Góra, Partyzantka na Podlasiu, pp. 88-94; T. Mencel, Walenty Lewandowski i poczatki powstania styczniowego na Podlasiu, p. 93; S. Chankowski, Powstanie styczniowe w Augu-stowskiem, p. 92; S. Łaniec, Partyzanci Kresów, pp.18-19; Idem, Litwa i Białoruś, p. 1; Idem Białoruś, p.40; Idem, Pótnocna Suwalszczyzna, p. 22

20 M.I. Cyłow, Sbornik rasporiażenij, p.306; W. Przyborowski, Historia 1863 r., vol. I, p. 201; S. Zieliński, Bitwy, pp. 320-321; S. Płoski, Działania Rogińskiego, p. 21; S. Góra, Działalność powstańcza Romana Rogińskiego na Podlasiu, pp. 378-399; Idem, Partyzantka na Podlasiu, pp. 97-98; S. Łaniec, Partyzanci Kresów, p.201; Idem, Litwa i Białorus, p. 62; Urzędowy wykaz, p. 281; „Czas” 1863, no. 48, 67; „Wiadomości z pola bitwy”, 1863 , no. 5. 21 S. Zieliński, Bitwy, p. 321; A.F. Smirnow, Wosstanie, pp. 133-134; S. Góra, Działalność powstańcza Romana Rogińskiego, pp. 399-401; Idem, Partyzantka na Podlasiu, p. 98; S. Łaniec, Partyzanci Kresów, p. 20; Idem, Białoruś, p.42; Idem, Litwa i Białoruś, p. 64; „Wiadomości z pola bitwy” 1863, no. 5; „Czas” 1863, no. 48, 57; „Chorągiew Swobody” 1863, no. 2; R. Rogiński, Kartki, p.446; Idem, Zeznanie, pp.61,64.

22 N. Berg, Zapiski o powstaniu polskim, p. 315; S. Zieliński, Bitwy, p. 314/321; C. Zgorzelski, Powstanie styczniowe na terenie woj. nowogródzkiego, Wilno 1934, pp.23-24; S. Góra, Działalność powstańcza Romana Rogińskiego, pp. 399-401; Idem, Partyzantka na Podlasiu, p. 98; S. Łaniec, Partyzanci Kresów, p. 21; Idem, Białoruś, p. 43; Idem, Litwa i Białoruś, p. 65; „Czas” 1863, no. 68; R. Rogiński, Zeznanie, pp. 64-69.

23 S. Zieliński, Bitwy, p. 314; S. Góra, Działalnosć powstańcza Romana Rogińskiego, pp. 399-401; Idem, Partyzantka na Podlasiu, p. 98; S. Łaniec, Partyzanci Kresów, p.21; Idem, Białoruś, pp. 43-44; Idem, Litwa i Białoruś, pp. 65-66. 
Assigned the task of organizing a unit he was facing a difficult challenge negatively influenced by, e.g. poor afforestation of the land and ,white nature” of the nationalists organization. The sole active commander in this region spent the first month of the insurrection training volunteers and avoiding encirclement although, in February 1863, he managed to enter several abandoned towns (Uniejów, Widawa) ${ }^{24}$. His next combat assignment, after joining with the cavalry of Aleksander Littich, was to harass the territories nearby the capital of governorate and to capture the town after a skirmish with General Brummer's border guard (25th of February 1863, Opatówek) ${ }^{25}$. Escaping the encirclement by three strong columns of major Rukteszel, which later turned into a fighting retreat during which approx. 180 people were able to escape, also required a great deal of command skills (26th of February, Kuźnica Grabowska) ${ }^{26}$. Eight day long escape from the enemy pursuit was interrupted with skirmishes e.g. a battle ending with a retreat during which insurrectionists repelled major Pisanko's battle-group consisting of 50 Cossacks and 85 rifleman, approx. 130 soldiers (3rd of March, Jawor) and a clash with the next group which resulted in the rout of 166 insurgents (5th of March, Brodnia) ${ }^{27}$. After restoration of the insurgent unit there were other skirmishes during which Oksiński with 150 subordinates was assaulted by nearly 200 infantrymen and 100 Cossacks under the command of major Merlin and fought his way down south (4th of April, Rudniki) and next eliminated a unit of Cossacks (11th of April, Praszka) ${ }^{28}$. May was a turbulent time for guerrilla fighters. After joining forces with Littich there was a skirmish of approx. 900-men strong unit with 4 units of infantry and 100 Cossacks commanded by colonel Pomieranow which ultimately resulted in the retreat of the insurgents - a unit of was kosynierzy routed, riflemen suffered casualties and the unit shrank to less than 500 men (8th of May, Rychłocice) $)^{29}$. Next the commander of insurgency in Piotrkowski poviat captured a small town and later defended it but was ultimately forced to abandon it when confronted with two-to-one numerical superiority of the unit led by major Bentkowski (25th of May, Koniecpol) ${ }^{30}$. Finally Oksiński launched an attack on a rail transport during which he was locked in a short combat engagement with 2 units of infantry (27-28th of May, Kłomnice-

24 A. Czubiński, Powstanie 1863/1864 na ziemi kaliskiej, „Zeszyty naukowe UiAM”, no. 47 Historia no. 6:1961, p. 42, 45; J. Oksiński, Wspomnienia z powstania polskiego, Warszawa 1965, pp. 44-45, 67, 69-70.

25 W. Przyborowski, Dzieje 1863 r., vol. I, p. 380; S. Zieliński, Bitwy, p. 191; Urzędowy wykaz, p. 304; ,Wiadomosci z pola bitwy”, 1863, no. 4; „Dziennik Poznański”, 1863, nr 49, 50; „Czas” 1863, no. 54, 55; J. Oksiński, Wspomnienia, pp. 91-92.

26 S. Gesket, Voennyje deistvija, p. 239; W. Przyborowski, Dzieje 1863 r., vol. II, p.247; S. Zieliński, Bitwy, pp. 191-192 A. Czubiński, Powstanie 1863/64, p.150; Urzędowy wykaz, p. 304; „Dziennik Powszechny” 1863, no. 54; „Wiadomości z pola bitwy” 1863, no. 5; „Dziennik Powszechny” 1863, no. 50,52, 55; „Czas” 1863, no. 54,55, 72; J. Oksiński, Wspomnienia, pp.93-102.

27 S. Gesket, Voennyje deistvija, pp. 284-285; W. Przyborowski, Dzieje 1863 r., vol. II, pp.248-249; S. Zieliński, Bitwy, p.193; A. Czubiński, Powstanie 1863/1864, p. 151; Urzędowy wykaz, p. 304; „Wiadomości z pola bitwy” 1863, no. 5; „Dziennik Powszechny” 1863, no. 54, 60; A. Giller, Polska w walce. Zbiór wspomnień i pamiętników z dziejów z dziejów naszego wyjarzmienia, vol. I, Paryż 1868, vol .I, Przegrana pod Rudnikami. Rzecz spisana z notat naocznego swiadka, p.200; J. Oksiński, Wspomnienia, pp.104-109.

28 S. Zieliński, Bitwy, pp. 195-196; Urzędowy wykaz, p.305; „Wiadomości z pola bitwy”, 1863, no. 8, 9; „Dziennik Poznański” 1863, no. 83; „Czas” 1863, no. 88.

29 S. Zieliński, Bitwy, p.; A. Czubiński, Powstanie 1863/64, p.173; J. Oksiński, Wspomnienia, pp.151-158; Urzędowy wykaz, p.306; „Wiadomości z pola bitwy” 1863, no. 12, 14; „Czas” 1863, no. 123, 130; „Dziennik Poznański” 1863, no. 119, 123, 124

30 W. Przyborowski, Dzieje 1863 r., vol. IV, p. 230; S. Zieliński, Bitwy, p.202; A. Czubiński, Powstanie 1863/64, p. 181; Urzędowy wykaz, p. 295; Wiadomości z pola bitwy 1863, no. 13 raport; „Dziennik Poznański” 1863 , no. 
Kruszyna) ${ }^{31}$. Several more fighting retreats of an 1400-men strong insurgent battle-group (3 infantry battalions, 1.5 cavalry squadron) were recorded, including: escape from encirclement and evading the pursuit and the retreat from the major general Czengiery battle-group (approx. 2400 soldiers -2 infantry battalions, 2 dragoon squadrons, artillery platoon equipped with two cannons) which resulted in a prompt dissolution of insurgency units (27-29th of June, Przedbórz - Trzepnica - Skotniki) ${ }^{32}$. Under the overall command of general Edmund Taczanowski Oksiński with his new unit engaged in several minor cavalry clashes (5th of July; 22nd of August, Złoczew - skirmish with the column under the command of colonel Tarasienkov) ${ }^{33}$, In the Fall he achieved several successes in the field of organization and logistics by forming small and mobile guerrilla units in the individual poviats and countys of Kaliskie region. The last display of Oksiński's effort to form more significant guerrilla fighting force was the so called Concentration in Iwanowice (350 infantrymen and 35 cavalrymen) ${ }^{34}$ which was, however, contrary to the overall military plan of insurgent forces commander in the voivodeship, Franciszek Kopernicki. The final military act of Oksiński and his men was repelling 240 soldiers under the command of captain Strauss ( 2 infantry units, 40 Cossacks) by 20 cavalrymen and 60 infantrymen barricaded in the premises of a local court ( 25 of February 1864, Chlewo ${ }^{35}$. The plans regarding the so called Greater Poland Expedition in the spring of 1864 fell flat due to, among other factors, violent and impetuous personality of Oksiński conflicted with commander-in-chief Kopernicki.

Teodor Cieszkowski during the pre-insurrection period he spent in Italy obtained both the education (Genoa-Cuneo) and military experience (voluntary service in forces of Garibaldi). Despite the presence of Apolinary Kurowski it was Cieszkowski who was the de facto commander of the February attack of 200-men strong group (half a squadron of cavalry, 50 kosynier soldiers, 50 rifleman, 50 volunteers) on the garrison of the border guard located in the area captured by the insurgents. The assault on the building of the train station resulted in success thanks to the clarity of mind and bravery of Cieszkowski who, after a momentary rout of insurgents resulting from failure to capture the building, regrouped his men and led them in the final, triumphant, attack (6th of February 1683, Sosnowiec) ${ }^{36}$. After a brief period in command of the forces staying in town (Dąbrowa Górnicza), the defeat at Miechów

\footnotetext{
$\overline{121 \text {; „Czas” } 1863}$, no. 119, 125; Sulima, Wspomnienia ułana z 1863 r., Poznań 1878, pp. 83-85: J. Oksiński, Wspomnienia, pp. 163-171.

31 S. Zieliński, Bitwy, p. 202; J. Kukulski, Z dziejów powstania styczniowego w Piotrkowskiem, Piotrków Trybunalski 1991, p. 29; „Czas” 1863, no. 123, 150; Sulima, Wspomnienia ułana, p. 94; J. Oksiński, Wspomnienia, pp. 172-173.

32 S. Zieliński, Bitwy, p. 206; J. Kukulski, Z dziejów powstania, p. 29, 31; A. Czubiński, Powstanie styczniowe 1863/64, p.182; Urzędowy wykaz, p.296; Sulima, Wspomnienia ułana, p.100; J. Oksiński, Wspomnienia, pp. 175, 189-200.

33 S. Zieliński, Bitwy, p. 210; A. Czubiński, Powstanie 1863/64, p. 193; Urzędowy wykaz, p.309; „Czas” 1863, no. 206; J. Oksiński, Wspomnienia, p. 332.

34 A. Czubiński, Powstanie 1863/64, p. 214.

35 S. Zieliński, Bitwy, p. 219; A. Czubiński, Powstanie 1863/64; „Gazeta Narodowa” 1863, no. 55, 56; „Głos z Litwy” 1863, no. 5; „Dziennik Poznański” 1863, no. 50; „Wiek” 1863, no. 19.

36 W. Przyborowski, Dzieje 1863 r., vol. I, p.143; S. Zieliński, Bitwy, p.160; P. Bańkowski, Z dziejów powstania styczniowego na Kielecczyźnie, „Pamiętnik Kielecki” 1947; R. Szwed, Powstanie styczniowe w Radomszczańskiem, Radomsko 1987, pp. 64-68; raport Kurowskiego do RN, 8 II in: Dokumenty terenowych władz wojskowych powstania styczniowego, Wrocław-Warszawa-Kraków 19, pp. 442-443; „Czas” 1863, no. 29,36; „Dziennik Powszechny” 1863, no. 32, 37; S. Szulc, Pamiętnik księdza kapelana in: Polska w walce, ed. A.Giller, vol.1, p. 86.
} 
(where 300 of Cieskzowski's subordinates arrived late for battle) and the medical treatment he received Cieszkowski started the period of independent activity lasting dozen or so days ${ }^{37}$. The raid launched from Krakowskie voivodeship to Kaliskie involved a skirmish during which Cieszkowski, attacked by forces of colonel Alenicz ( 2 units of infantry, 50 Cossacks, 450 men and two cannons in total), retreated in an orderly fashion and escaped the pursuit (26th of February, Pańki) ${ }^{38}$. After the return to Krakowskie voivodeship he contained the situation during the unexpected enemy attack and repelled the assault on the town and, by attacking the rearguard of the enemy and confused and routed the pursuit group of Alenicz (1st of March, Mrzygłód $)^{39}$. After two-weeks stay with the corpus of Marian Langiewicz he embarked on a unit forming and diversionary mission in the southern part of Kaliskie voivodeship attacking small garrisons (14th of March, Radomsko), destroying electric traction, bridges and railway connections ${ }^{40}$. Two following engagements he participated in consisted of defending insurgent camps: due to the negligence of security measures Cieszkowski was unexpectedly attacked by 400 enemy soldiers from 2 infantry units of major Leon from Częstochowa (22nd of March, Kuźnica Masłowska) which forced insurgents, surrounded on three sides, to turn back to Krakowskie ${ }^{41}$. The other defensive engagement with forces of major Pisanko ( 2 units of infantry, 100 Cossacks - 490 soldiers) turned at times into an offensive skirmish so much so that the final counterattack of insurgents forced Russians to retreat (27th of March, Radoszewice $)^{42}$. Due to the short lived break in his activity resulting from the necessity to disband his unit, unfit for further combat, Cieszkowski returned to organizational assignments. The life of perpetually relocating commander ended during the skirmish between the small, 28-men strong, unit and nearly 500 infantrymen and Cossacks led by major Merlin (10th of April, Broszęcin) ${ }^{43}$.

The other citizen from Kresy trained and educated in Polish Military School in Italy, Feliks Wysłouch, is considered to be the founder of the first transitory guerrilla unit in Lithuania which was supposedly formed by the end of January 1863 (Zułów). Since the very beginning the initiative of insurgents was aimed at capturing the town (7th of February 1863, Żeladź) but there Wysłouch was defeated by a platoon of the Newski infantry regiment and

\footnotetext{
37 W. Przyborowski, Dzieje 1863 r., vol. I, p.241; S. Zieliński, Bitwy., p. 160; W. Tokarz, Kraków w początkach powstania styczniowego i wyprawa na Miechów, Kraków 1914, vol. II, p.156; P. Bańkowski, Z dziejów powstania, p. 139.

38 S. Gesket, Voennyje deistvija., p. 2 81; W. Przyborowski, Dzieje 1863 r., vol. II, p.200; S. Zieliński, Bitwy, p. 192; Urzędowy wykaz, p. 304; „Wiadomości z pola bitwy” 1863, no. 5; „Dziennik Poznański” 1863, no. 5.

39 S. Gesket, Voennyje deistvija., p. 281; W. Przyborowski, Dzieje 1863 r., vol. V, p. 20; S. Zieliński, Bitwy, p.163; R. Szwed, op. cit., p.83; „Wiadomości z pola bitwy” 1863, no. 5; „Czas” 1863, no. 50; „Dziennik Poznański” 1863, no. 55, 67; „Dziennik Powszechny” 1863, no. 54; S. Szulc, Pamiętnik w: W 40 rocznice, p.101.

40 S. Zieliński, Bitwy, p.193; „Czas”1863, no. 61,63; „Dziennik Poznański” 1863, no. 84.

${ }_{41}$ S. Gesket, Voennyje deistvija, p. 286; S. Zieliński, Bitwy, p.166; R. Szwed, op. cit., p.110, 112; Urzędowy wykaz, p. 293; „Wiadomości z pola bitwy” 1863, no. 7; „Czas” 1863, no. 69, 70; „Dziennik Poznański” 1863, no. 71.

42 S. Zieliński, Bitwy, p.195; J. Kukulski, Z dziejów powstania, p.26; A. Barszczewska, Udział Łodzi i okręgu łódzkiego w ruchach narodowowyzwoleńczych 1795-1864, Łódź 1971, p. 281; T. Olejnik, Bitwa pod Radoszewicami 27 III 1863. Przyczynek do dziejów powstania styczniowego na ziemi wieluńskiej, „Sieradzkie Roczniki Muzealne”, t. 6: 1986, p.81-94; „Wiadomości z pola bitwy” 1863, no. 8; „Dziennik Poznański” 1863, no, 73, 75-raport Calliera; „Czas” 1863, no. 73, 76; „Dziennik Powszechny” 1863, no. 71.

43 S. Zieliński, Bitwy, pp. 195-196; J. Milczarek, Powstanie styczniowe w Sieradzkiem, Sieradz 1983, p.23; S. Szulc, op. cit., p.109; Urzędowy wykaz, p.305; „Wiadomosci z pola bitwy” 1863, no. 9; „Czas” 1863, no. 85,89, 90; „Dziennik Poznański” 1863, no. 91.
} 
half a squadron of Cossacks and forced to retreat and disband his men ${ }^{44}$. After the recess he participated in another, inconclusive, skirmish (22nd of February, Daukszyszki) ${ }^{45}$. As the military commander of the spring uprising in Troki Wysłouch, along with 130 men, fought a defensive battle on the position captured courtesy of the information provided by scouts and repelled the unit of captain Fiedotow (16th of April, Antokolce) ${ }^{46}$. Then he submitted to the command of Horodeński-Kieżgajło and A. Stabrowski and with commander Horodeński led his unit of 320 insurgents to a victory in battle against 1000-men strong column of colonel Kremer (30th of April, Szeszole) ${ }^{47}$. After the battle between his group and the units of colonel Tisdel, during which groups of Stabrowski and Jan Sendek were divided, Wysołuch with 250 subordinates was surrounded by the column of lieutenant colonel Czekiesow from the Kostromski infantry regiment ( 2 units, 20 Cossacks - approx. 610 soldiers) but was able to break encirclement (11th of July, Żyżmory ${ }^{48}$. After a month of pursuit he decided to engage 200-men strong unit of Tisdel in combat. At first he was successful (20th of July, Antopojce) but on the following day his unit was defeated and broken (21st of July, Petraszyszki) ${ }^{49}$. His operations consisted of marching his units and engaging patrolling enemy units of infantry, cavalry and Cossacks in skirmishes. The activities of Wysłouch during the uprising ended on a high note: during the closing stages of the insurrection in Wilno he assaulted the enemy pacification group and leading approx. 400 soldiers routed an enemy infantry unit and 100men strong Cossack unit, approx. 245 tsarist soldiers (20th of October, Żyżmory) ${ }^{50}$.

\section{Promising commanders}

Aleksander Littich, submitting to the overall command of Józef Oksiński, a coleague from the Polish Military School in Italy, cooperated with him since 1863 in the capacity of the cavalry commander in Kaliskie and Sandomierskie voivodeships and, since April, as a founder of guerrilla units. The balance of somewhat coincidental independence of his command (after separation during a battle) is inconclusive, similarly to the first clash of the forces of Wielun uprising commander with two infantry units and 50 Cossacks under

44 S. Zieliński, Bitwy, pp.276-277; J. Jakubianiec-Czarkowska, Powstanie w powiecie święciańskim, Święciany 1934, pp.21-29; A.F. Smirnow, Wosstanije, pp.138-139; S. Łaniec, Białoruś, p.51; Idem, Powstanie styczniowe na Litwie, Olsztyn 2000, pp.47-48; Idem, Litwa i Białoruś, p.67.

45 A.I. Miłowidow, Piereczien bojewych stolknowieenij, p.3.

46 S. Zieliński, Bitwy, pp.278-279; M.I. Cyłow, Sbornik rasporiażenij, p.307; A.Smirnow, Wosstanije, pp.138-139; S. Łaniec, Powstanie styczniowe na Litwie, pp.61-62; Idem, Litwa i Białoruś, p.82; „Wiadomości o powstaniu na Litwie” 1863, no. 3; „Wiadomości z pola bitwy” 1863, 22 IV, 28 IV; „Czas” 1863, no. 94, 98, 102, 103; „Dziennik Poznański" 1863, no. 94

47 S. Zieliński, Bitwy., p. 280; M.I. Cyłow, Sbornik rasporiażenij, p. 307; A. Krzyszkowska, Powstanie styczniowe na Wileńszczyźnie, Wilno 1934, pp. 37-38; S. Łaniec, Powstanie styczniowe na Litwie, p. 63; Idem, Litwa $i$ Białoruś, pp.83-84; „Wiadomości o powstaniu na Litwie” 1863, no. 5; „Dziennik Poznański” 1863, no. 108; „Czas” 1863, no. 107, 108.

48 S. Zieliński, Bitwy, p. 285; M.I. Cyłow, Sbornik rasporiażenij, p. 310; A. Krzyszkowska, Powstanie styczniowe na Wileńszczyźnie, p.38; S. Łaniec, Powstanie styczniowe na Litwie, p.119; Idem, Litwa i Białoruś, p.153

49 S. Zieliński, Bitwy, p.285; A. Krzyszkowska, Powstanie styczniowe na Wileńszczyźnie, p. 39; S. Laniec, Powstanie styczniowe na Litwie, p. 120; Idem, Litwa i Białoruś, p.154; „Czas” 1863, no. 200, 205; „Dziennik Poznański” 1863, no. 205, 210.

50 S. Zieliński, Bitwy, pp. 286, 306-308, 539; L. Ratajczyk, Polska wojna partyzancka 1863-1864. Okres dyktatury Romualda Traugutta, Warszawa 1966, p. 224; S. Łaniec, Powstanie styczniowe na Litwie, p. 138-139; Idem, Litwa i Białoruś, p.174; „Czas” 1863, no. 254, 255. 
the command of colonel Suwarów (450 soldiers) Littich was forced into (23rd of April 1863, Wąsosz-Więcki ${ }^{51}$. Avoiding the encirclement he relocated battle-line from the riverside into the forest where he engaged enemies in a firefight interrupted by assaults of Cossacks. During the retreat Littich's forces were routed. In the following days he paid for breaking the unit led by officer Kriukow (3rd of July, Kaszewice) by his slightly larger, 60-men strong unit, with an unexpected rout of the insurgents' camp by the unit led by lieutenant Fiedorow and the survivors of Kriukow's unit (4th of July, Chorzenice) ${ }^{52}$. He took his last independent command as late as in the Fall taking over the remains of Mazovian group formerly led by Robert Skowroński.

Maksymilian Waclaw Broniewski, the graduate of the Italian migratory institution, began his combat trail with organizing an armed unit in Płockie towards the end of January 1863. In February he joined forces with Władysław Cichorski-Zameczek and learned the craft of war fighting alongside different poviat commanders in order to lead the battle-group in Ostrołęckie as the commander of the largest unit. There he participated in a multi-stage battle during which the former units of Karol Fryga (600) and Polikarp Dąbkowski (approx. 200 cavalrymen) led by Broniewski joined with forces of Ludwik Lutyński (200 rifleman), peasant formations of Stanisław Mańkowski (100) and Jan Nowak (50) and other disorganized elements and with approx. 1200-1400 men received the assault of 3 units of infantry, a squadron of hussars and 50 Cossacks led by major general Toll, major Zass and major Suchotin (approx. 850 soldiers). Inconclusive battle ended with a retreat when Russian forces received reinforcements (3rd of June 1863, Nagoszewo) ${ }^{53}$. According to other recollection of these events firstly units of insurgents attacked the Russian standing column (2 units of infantry, 2 squadrons and a sotnia - approx. 830 soldiers) then were forced to repel the column led by Suchotin ( 3 units, squadron of hussars and Cossacks - approx. 830 soldiers) and finally were forced to retreat while fighting with columns of major Zass ( 3 units -600 soldiers) and general Toll (3 units - 600 soldiers). Approximately 2850 Russian soldiers fought in this battle. The role of Polish commander can be observed during the second stage of fighting when he attempted to utilize the advantages forest and marshy terrain provided to launch a double ambush using infantry. The weakness of human element turned the clash into a defensive battle and the intervention of local peasants further devolved battle into a pursuit. The coming of the last enemy column meant that insurgents had to break through the flanks towards the river and divide their battle-group. Broniewski once again submitted himself under the command of others.

51 S. Zieliński, Bitwy, p.198; J. Gąsiorowski, Bitwa pod Wąsoszem 23 kwietnia 1863 r., Częstochowa 1938; A. Czubiński, Powstanie 1863/64, p.45; J. Związek, Bitwa pod Wasoszem (23 IV 1863) na tle walk powstańczych na Ziemi Częstochowskiej, „Częstochowskie Wiadomości Diecezjalne”, r.57: 1983, no. 19, pp. 206-219; Urzędowy

wykaz, p.306; „Wiadomości z pola bitwy” 1863, no. 10 raport; „Dziennik Powszechny” 1863, no. 96; „Czas” 1863, no 94,97,98, 99; „Dziennik Poznański” 1863, no. 98.

52 S. Zieliński, Bitwy, p. 207; Urzędowy wykaz, p.308; „Dziennik Poznański” 1863, no. 160; „Czas” 1863, no. 161, 162.

${ }^{53}$ N. Berg, Notatki o polskich powstaniach., vol. III, p.226; W. Przyborowski, Dzieje 1863 r., vol. IV, p.276; S. Zieliński, Bitwy, p. 236; M. Bartniczak, Bitwa pod Nagoszewem 3 VI 1863, „Rocznik Mazowiecki”, 1972, vol.4. p. 181; S. Góra, Partyzantka na Podlasiu, p.141; Urzędowy wykaz, p. 317; „Wiadomości z pola bitwy” 1863, no. 15; „Dziennik Powszechny” 1863, no. 125; „Czas” 1863, no. 132, 156; Z. Chądzyński, Wspomnienia powstańca z lat 1861-1864, Warszawa 1963, pp. 122-123; Pamiętnik powstańca Wacława Broniewskiego, BUW, rkps 1345; Rys życia M.W. Bro-niewskiego, BN, rkps II 6515, k.26, 28, 30, 31, dod. 30. 
Bolesław Kolyszko is one of the two cadets related with the Lithuanian theater of military operations participating in the migratory military course. Hailing from the Wileńskie area he entered into the records of the insurrection in the Kowieńszczyzna region. His achievement was transforming volunteers coming to his camp into a quasi-regular 400-men strong unit, so called Dubiski regiment. However, insufficient training and equipment in connection with neglecting security measures resulted in the failure of efforts to stop the attack of Kaporski infantry regiment led by major Stepanow (approx. 3300-3600 soldiers) and in conjunction with the Russian attack on the rear positions of the Polish formation resulted in the rout of Kołyszko's subordinates (29th of March 1863, Wysoki Dwór) ${ }^{54}$. In the riverside skirmishes of the thousand-men strong group of insurgents led by Tomasz Kuszłejko Kołyszko was in command of the right flank - at first in the fight against two columns from Rosienie and Kiejdany, nearly two thousand-men strong, and later in the firefight with approx. 900 enemy soldiers (1st and 5th of April, Lencza) ${ }^{55}$. Further division of his unit (at that time counting 70 insurgents) nearly resulted in its destruction at the hands of 2.5 units (500 soldiers) led by colonel Bożerianow. However, Kołyszko was able to break encirclement and retreat deep into the forest (11th of April, Misiuny) $)^{56}$. Further military exploits of Kołyszko are related with the campaign led by Zygmunt Sierakowski who, recognizing talents of the newcomer, promoted him and during the march for Kurland gave Kołyszko the command of the leftflank column (I and III battalion, approx. 300-400 men) heading for Birża. It was he who initiated the three-day long battle in Żmudź (7th of May, Hudyszki) ${ }^{57}$. Kołyszko kept the column of major Merlin (1.5 unit of the Kaporski infantry regiment, 70 Cossacks - approx. 320 soldiers) locked in battle until he was relieved by the next battalion and marching column of Sierakowski. On the following day, waiting for the relief forces of Fr. Antoni Mackiewicz, he fought until he was overwhelmed by the reinforced forces of the enemy. On the 9th of May Kołyszko was captured and on the 3rd of June he was executed in Wilno ${ }^{58}$.

\footnotetext{
54 Miłowidow, Pierieczeń bojewych stolknowienij, vol. II, p.94; N.I. Cyłow, Sbornik rasporiażenij., S. Zieliński, Bitwy, p. 288; A. Smirnow, Wosstanije, pp. 148-151; W. Karbowski, Kampania Zygmunta Dotegi-Sierakowskiego na Żmudzi w 1863 r., „SiMdHW”, vol. XXI, 1978, p. 234; p. 306; S. Łaniec, Litwa, p. 28; Idem, Powstanie styczniowe na Litwie, pp.56-57; Idem, Litwa i Białoruś, p.73; Idem, Rajdy partyzanckie i bitwy Bolestawa Kotyszki na Kowieńszczyźnie (wiosna 1863 roku) in: Spoleczeństwo i polityka w dziejach Polski i Europy. Studia do dziejów politycznych i wojskowych dedykowane Profesorowi Benonowi Miskiewiczowi z okazji jubileuszu 70-lecia urodzin, edd. A. Czubiński, B. Lapis, Cz. Łuczak, Poznań 2002, pp. 418-419; „Ojczyzna” 1864 no. 124 Monografie; „Dziennik Poznański” 1863, no. 81,94; „Wiadomości z pola bitwy”, 1863 no. 8; „Czas” 1863, no. 82,84,86; „Ojczyzna” 1865, no. 69; J. Laskarys, Wyprawa Sierakowskiego na Kurlandię w 1863 r. in: Pismo zbiorowe. Towarzystwo Naukowe Młodzieży Polskiej, vol.1:1865, Bendlikon, pp. 37-43.

55 S. Zieliński, Bitwy, pp. 288-289; A. Smirnow, Wosstanie, p. 50; S. Łaniec, Litwa, p. 34; Idem, Powstanie styczniowe na Litwie, pp. 77-78; Idem, Dowódcy i bohaterowie powstania, pp.44-45; „Wiadomości z pola bitwy” 1863, no. 9; „Wiadomości o powstaniu na Litwie” 1863, no. 3 - raport naczelnika woj. kowieńskiego; „Czas” 1863, no. 91, 93, 261-korespondencja ze Żmudzi 1 XI; „Dziennik Poznański” 1863, no. 94; J. Laskarys, Wyprawa Sierakowskiego, pp.40-41.

56 S. Zieliński, Bitwy, p. 289; A. Smirnow, Wosstanije, p. 151; S. Laniec, Litwa, p.39; Idem, Powstanie styczniowe na Litwie, p. 80; Idem, Litwa i Białorus, pp. 93-94; Wosstanije w Litwie i Biełorussii 1863-1864, WrocławWarszawa-Kraków, p. 201-Zeznanie Kolyszki.

57 A. Smirnow, Wosstanije, p. 197; W. Karbowski, Kampania Dotęi-Sierakowskiego, pp.273-274; S. Łaniec, Zygmunt Sierakowski, Olsztyn 1999, pp. 80-81; Idem, Litwa, p.55.

58 5W. Przyborowski, Dzieje 1863 r., vol. III, pp. 99-100, S.I. Cyłow, Sbornik rasporiażenij, p. 49; S. Zieliński, Bitwy, pp. 293-294; A. Smirnow, Wosstanie, pp.198-200; W. Karbowski, Kampania Dotęi-Sierakowskiego, p.278, 281; S. Łaniec, Sierakowski, pp. 83-85; Idem, Litwa, pp. 58-59; Wosstanie w Litwie i Biełorussii, pp. 201-202.
} 
Pawel Suzin intended to join the insurrection as soon as in February 1863 but his unit, intended to be used in breaking through the cordon in Płockie, was dispersed by Prussian army. In May he led a small group of volunteers in the Marimpolski poviat of Augustowskie voivodeship. Shortly after joining forces with W. Kamiński's group (4th voivodhsip unit consisting of 265 armed and 40 unarmed men) and participated in a skirmish between Polish and Russian scouting parties (22nd of May, Poszławanty) $)^{59}$. Major battle with the column of colonel Manowski (2.5 units of infantry, Cossacks, squadron of dragoons more than 700 soldiers and 2 cannons) started with insurgents' vanguard getting locked in fight (23rd of May, Buda/Balwierzyszki) ${ }^{60}$. Insurgents, fired upon with rifles and later with 2 cannons, took cover behind the buildings and retreated into forest continuing the firefight along the way. Facing encirclement Suzin moved deeper into the forest and when the enemy retreated he returned to his previous station. Suzin's unit destroyed railway and telegraphic communication, conducted a series of manoeuvres beside the border and moved from the northern to the southern part of the voivodeship. Commanding his own unit and the units of Kamiński, Hłaski and Brandt, despite being under pressure of 5 units of infantry accompanied by a squadron of hussars and 2 cannons, he set up a riverside ambush and fired upon the enemy infantrymen and cavalry led by captain Stern vel Gwiazdowski (a unit of guard, cavalry - approx. 200 soldiers) who retreated after a firefight (20th of June, Olita) ${ }^{61}$. Insurgent units of Suzin, Brandt, Hłaski and Józef Gleba-Kazański relocated their campsite and after scouting terrain took the defensive position by the lake (21 VI Stragiszki $)^{62}$. Facing the roughly equal or slightly larger Russian forces of Captain Stern vel Gwiazdowski and colonel Skordula (3 infantry units and Cossacks - more than 600 soldiers in total) instead of preparing an ambush, which would allow insurgency forces to take position on the rear of the enemy, the insurrectionist vanguard alarmed the approaching enemy. The decision of Suzin to personally lead the rifle cannonade induced confusion in the ranks of enemy and thus Polish commander decided to attempt to encircle Russians' right flank with a unit of Kosynierzy and attack their rear. Due to the negative influence of cannonade on the unit

\footnotetext{
59 S. Zieliński, Bitwy, pp. 259-260; S. Chankowski, Powstanie styczniowe w Augustowskiem, p. 122; I. Karpowicz, Imć Pana Rotmistrza, powstańca z r. 1863 wspomnienia, Wilno 1928., pp. 66-69.

60 S. Zieliński, Bitwy, pp. 259-260; S.I. Cyłow, Sbornik rasporiażenij, p. 308; Z. Kolumna,[A.Nowolecki] Pamiątka dla rodzin polskich: krótkie wiadomosci biograficzne o straconych na rusztowaniach, rozstrzelanych, polegtych na placu boju, oraz zmartych w więzieniach, na tułactwie, Kraków 1868, vol.II, pp. 62-63; S. Chankowski, Powstanie styczniowe w Augustowskiem, p.122; Urzędowy wykaz, p. 322; „Wiadomości z pola bitwy” 1863, no. 12, 13; „Czas” 1863, no. 129, 130; „Dziennik Poznański” 1863, no. 120; 124 raport Suzina, 127, 132; „Nadwiślanin” 1863 no. 61 ; S. Katyll, Opis bitew stoczonych w r.1863 pod Balwierzyszkami i pod Staciszkami. Śmierć Pawła Suzina, „Zdrowie” 1904, pp. 235-239; R. Błoński, Pamiętnik z Augustowskiego 1863 r. in: Polska w walce. Zbiór pamiętników, ed. A. Giller, vol.2, Kraków 1875, pp. 396-398; W. Brandt, Mój udzial w powstaniu w: W 40 rocznicę, Lwów 1903, pp. 78-79.

61 S. Zieliński, Bitwy, p.261; N.I. Cyłow, Sbornik rasporiażenij, p. 309; Krzyszkowska, Powstanie $w$ pow. święciańskim, p. 27; S. Łaniec, Powstanie styczniowe na Litwie, pp.69-70; Idem, Pólnocna Suwalszczyzna, p.43; R. Błoński, Pamiętnik z Augustowskiego 1863 r., p. 391, 399; „Dziennik Poznański” 1863, no. 167-raport; „Czas” 1863, no. 146, 147, 157; „Niepodległość” 1867 no. 36.

62 Z. Kolumna, op. cit., part II, p. 63; S. Zieliński, Bitwy, pp.261-262; S. Chankowski, op.cit., p.123; S. Łaniec, Partyzanci Kresów, pp.104-105; Idem, Powstanie styczniowe na Litwie, pp. 69-70; Idem, Pólnocna Suwalszczyzna, pp. 43-44; raport Andruszkiewicza dla RN 14 VII 1863; Dokumenty terenowych wladz wojskowych, pp. 40-41; „Czas” 1863, no. 147; „Dziennik Poznański” 1863, no. 156, 167; Sz. Katyll, Opis bitew, pp.240-250; R. Błoński, Pamiętnik z Augu-stowskiego, pp. 398-401; I. Karpowicz, Pamiętnik Imć Pana Rotmistrza, pp. 74-75.
} 
of Kosynierzy Suzin decided to withdraw them but was killed himself during the retreat. It resulted in the dispersion of the unit not supported by the forces of Hłaski.

\section{Mediocre commanders}

Command skills of Wladysław Jabłoński can be evaluated by examining one of the major battles of the uprising (3rd of February, 1863, Węgrów) ${ }^{63}$. Battle-group consisting of three thousand men resisted the assault of the enemy columns (attacking from the north -3 battalions from Wołyński, Halicki and Witebski infantry regiments, a sotnia unit of Cossacks and 2 cannons from the 2 nd artillery brigade formed into two columns led by lieutenant colonel Kriwonosow from Małkinia and lieutenant Botemps from Łochów; attacking from the south - Siedlce column led by colonel Papaafanasopulo - 9th, 11th and 12th infantry unit of the Kostromski infantry regiment, 4th Ulan squadron of the Smoleńsk infantry regiment, one other unidentified squadron and a division of mounted artillery - approx. 900 men, 4 cannons). In the main battle itself approx. 2000 insurgents fought against the subordinates of the tsarist officer of Greek origin.

Jabłonowski, hailing from the Podlasie region, formally in joint command of the group with Jan Matliński, took the entirety of the burden of command. The decision to deal with each of the approaching columns separately is considered a good one. Therefore the initial clash of the slightly larger (by approx. 10\%) insurgent group with a singular Russian column resulted in a minor success - the march of the column was halted, information concerning the strength of the enemy and their direction were gathered and the town was warned (Jabłonowski led the cavalry charge personally). However, larger offensive actions were foregone. Patriotically and emotionally motivated decision to defend Węgrów, made during the meeting of commanders, resulted in, due to Węgrów being located on the river bank, near crossroads and surrounded by hills, relinquishing the advantageous position to the enemy and if enemy possessed artillery units would made the realization of the plan impossible. The attempt to command the entirety of the forces located in the city was an ambitious one but due to Jabłoński being wounded Matliński had to improvise the defense of town. Chief of Staff took over the responsibilities of the commander-in-chief and Jabłonowski is mentioned in historical sources as the initiator of the defensive actions covering the retreat of the battle-group. Commanding a unit of rifleman and, most importantly, a unit of kosynierzy who counterattacked the encroaching enemies with such ferocity that they nearly captured enemies' cannons, he secured the retreat of insurgents so skillfully that they evaded encirclement and pursuit. The commitment and bravery of the commander, as well as the lack of practical experience, are undeniable. Leading the largest but poorly trained insurgent battle-group into a fight with a regular, well equipped and prepared enemy formation proved to be beyond the capabilities of the adolescent "Genose". He was unable to capitalize on

\footnotetext{
63 W. Przyborowski, Dzieje 1863 r., vol. I, pp.178-179; S. Gesket, Voennyje deistwija, pp.169-173; S. Zieliński, Bitwy, pp. 335-340; E. Kozłowski, Od Wegrowa do Opatowa, 3 II 1863-22 II 1864, Wybrane bitwy z powstania styczniowego, Warszawa 1962, p.; S. Góra, Partyzantka, pp. 81-86; „Wiadomości z pola bitwy”, 1863 no. 1; „Czas” 1863 no. 34; „Dziennik Powszechny” 1863, no. 28; „Dziennik Poznański” 1863, no. 31, 36; T. Wyszomirski, Bitwa pod Węrowem stoczona przez powstańców z wojskiem carskim 3 II 1863 w świetle relacji jej uczestnika Stanisława Krzemieniew-skiego, „SiMdHW”, 1962, vol.III, part.2, p. 327; Urzędowy wykaz, p.28; N. Wronowski, Węgrów. Siemiatycze in: W 40 rocznicę, p. 513; F. Lewicki, Węgrów. Obrazek historyczny pamięci przyjaciela, Stanisławów 1881; W. Jabłonowski, Pamiętnik, Biblioteka PAN Kraków 2189/1, vol.1, pp. 436-437.
} 
the numerical superiority of his forces ( 3.5 to 1,2 to 1 during the defense of the town) or the evident mistakes made by the enemy. Both commanders of the shrinking battle-group, despite joining with the Zabuże forces, avoided combat (6th of February, Siematycze) ${ }^{64}$. When Teodor Cieszowkski fell ill Jabłonowski took command of his unit but after the catastrophe in Miechów he panicked and departed for Galicia ${ }^{65}$.

\section{Poor commanders}

Wiktor Jurkowski was able to utilize his theoretical knowledge acquired in the migratory institution mainly in the field of organization and logistics (in March, April and June of 1863) because his four attempts to take command of forces in Płockie region resulted in a disaster. Commanding inexperienced subordinates, instead of hiding with his 100-men strong unit deep in the forests, he camped in a village where, due to the negligence of security measures, he was attacked by the group of yesaul [tn - a Cossack officer] Dukmasow (120 infantrymen, 40 Cossacks). Jurkowski was defeated and forced to retreat with the survivors (12th of March 1863, Rydzewo ${ }^{66}$. He was once again surprised while drilling 150 volunteers nearby the defensively located camp. Despite several attempts he was unable to form a battle-line against the infantry unit of captain Prowolski (14th and 16th of April, Skępe and Koziołek) ${ }^{67}$. A regrouping unit of 300 men broke the group of ensign Wasilewski (4th of June, Bąkowo) ${ }^{68}$ and ultimately approx. 245 soldiers from an infantry unit and 50 Cossacks under the command of captain Kenstowicz (9th of July, Szczutowo-Blizne) ${ }^{69}$. Jurkowski relinquished the command to the military commander of Lipnowki poviat, major Piotr Czarliński.

Anastazy Mossakowski, an unremarkable commander of the April expedition to Galicia appeared to be apathetic and lacking faith in himself and the success of the endeavor. It is striking as he supplemented practical experience acquired during the Garibaldi's expedition with theoretical knowledge acquired in Genoa and Cuneo. The realization of a plan to join forces with the group of Józef Oksiński in forests of the Krakowskie voivodeship proceeded swiftly despite the lack of food and poor weather conditions. The clash between 317 insurgents (rifleman, kosynierzy and cavalry) and the encountered enemy infantry and cavalry units resulted in repelling the cavalry facing the risk of being outflanked and ousting Russians

64 See footnote no. 19.

65 See footnote no. 37.

66 N. Berg, Zapiski o polskich powstaniach, vol. VIII, p. 70,80; W. Przyborowski, Dzieje 1863 r., vol. II, p.207, 213; S. Gesket, Voennyje dieistvija, pp. 319-320; S. Zieliński, Bitwy, p. 228, 436; W. Karbowski, Zygmunt Padlewski, Warszawa 1969, p. 344; R. Juszkiewicz, Powstanie styczniowe na Pólnocnym Mazowszu, Warszawa 1992, p. 38; Urzędowy wykaz, p.316; „Wiadomości z pola bitwy” 1863, no. 6,7, 10 of 10 V; „Czas” 1863, no. 62, 64, 75; „Dziennik Poznański” 1863, J. Sawicki-Stella, Ludzie i wypadki z 1861-1865 r., Lwów 1894, vol. I, p.78; L. Nałęcz-Przetocki, Walki pod Wilkoszewskim i Padlewskim w:W 40 rocznicę,Lwów 1903, p. 356; Z. Chądzyński, Pamiętnik, p. 112, 137, 140, 194.

${ }^{67}$ N. Berg, Zapiski o polskich powstaniach,.vol. VII, pp.84-85; R. Juszkiewicz, Powstanie styczniowe na pólnocnym Mazowszu, p. 53.

68 S. Zieliński, Bitwy, p. 237; Urzędowy wykaz, p. 317.

69 S. Zieliński, Bitwy, pp. 239-240; Z. Grot, Rok 1863 w zaborze pruskim. Udzial spoleczeństwa w powstaniu styczniowym, Poznań 1963, p. 144; R. Myśliborski-Wołowski, Udział Prus Zachodnich w powstaniu styczniowym, Warszawa 1969, p.158, 159; R. Juszkiewicz, Powstanie styczniowe na Pótnocnym Mazowszu, p. 68; Urzędowy wykaz, p. 317; „Niepodległość” 1863, no. 3; „Czas” 1863, no. 167, 172; Z. Chądzyński, Pamiętnik, p. 83. 
from the village in close quarter combat (22nd of April 1863, Golczewice) $)^{70}$. His subordinates, exhausted and not able to keep with the marching pace, begun to complain and desert when a needless detour was made (sparked by the rumors about a convoy transporting Polish prisoners of war, the idea to destroy railway). Mossakowski choose a good place to camp but the battle formation he arranged his forces in to meet the several times larger enemy column of colonel Alenicz (3 infantry units) broke when the left flank company fled despite the supporting charge of kosynierzy unit (24th of April, Jaworznik) ${ }^{71}$. Mossakowski lost his head, left the battlefield and members of the expedition turned back to Galicia

\section{Commanders difficult to assess}

"The Genose" Józef Tłuchowski, alias Borowy [tn - Borowy aka Lechy is a daemon from Slavic mythology, master of the forests], cavalry commander in the Płock area did not have a chance to demonstrate his skills in command because the unit he formed, consisting of 102 cavalrymen, was immediately dispersed by the enemy (13th of June 1863, Kowalewo) ${ }^{72}$.

Leopold Czapiński, member of the Intelligence from Podlasie, stood by Aleksander Szaniawski during the bloodless attack of 250 conspirators on a squadron of ulans from the Smoleńsk infantry regiment expelled from their positions during the January Night (22/23rd of January 1863, Łomazy) $)^{73}$. Later he was an officer in various insurgent groups.

Faustyn Gryliński and Robert Skowroński, apart from the experience acquired in the Austrian army, prided themselves in participating in supplementary course in the migratory institution in Cuneo. Military disposition of them both, rather discrediting and mediocre than distinguishing, was discussed in greater detail elsewhere ${ }^{74}$.

\section{Conclusion}

The command careers of approx. $5 \%$ of the insurrectionist commanders, whose substantive preparation was restricted to a few months-long training in the migratory institution, were analyzed. Four individuals can be deemed to be outstanding commanders in the insurrectionwide scale (Rogiński, Oksiński, Cieszkowski, Wysłouch). Further three (Littich, Broniewski, Kołyszko, Suzin) should be ranked as gradually developing and promissing commanders. One of the commanders (Jabłonowski) was mediocre in the context of the insurrectionist average and, in contrast, the next two commanders (Jurkowski, Mossakowski) were undeniably incompetent. Taking into account the Austrian officers (Gryliński, Skowroński) we may

\footnotetext{
70 W. Przyborowski, Dzieje 1863 r., vol. IV, p.217, 290; S. Zieliński, Bitwy, p. 167; „Wiadomości z pola bitwy” 1863, no. 10 of 7 V; „Czas” 1863, no. 92, 94, 96, 97; Gazeta Narodowa no. 52, 66; S. Wierzbiński, Opisanie wojennych wypraw, w których brałem udziat, in: A. Giller, Polska w walce, p. 171, 184, 185; C. Pieniążek, Lat temu 27. Kartki z pamiętnika, Kraków 1890, pp. 81-88; E. Klebert, Wyprawa Mossakowskiego in: W 40 rocznicę, p. 194.

71 S. Zieliński, Bitwy, pp. 167-168; E. Kozłowski, Wyprawy wojenne, p. 126; Urzędowy wykaz, p. 294; remaining bibliographic data as in footnote 52 .

72 S. Zieliński, Bitwy, p. 237; „Czas” 1863, no. 159.

73 N. Berg, Zapiski o polskich powstaniach; W. Przyborowski, Dzieje, vol. I, p. 101; S. Zieliński, Bitwy, p. 57; J. Tomczyk, Organizacja cywilno-wojskowa powstania styczniowego, p. 39; S. Góra, Partyzantka, pp. 63, 65.

74 Because of the fact that the provenance of the partitiotner armed forces was a deciding factor during the insurgency. See:. A. Buława, Byli oficerowie armii austriackiej jako dowódcy powstańczych oddziałów zbrojnych (18631864) in: Gloria victis 1863 r., Studia i szkice z dziejów Powstania Styczniowego, ed. T. Matuszak, WarszawaPiotrków Trybunalski, pp. 57-60.
} 
indicate four incapable commanders. Two of the commanders were deemed difficult to objectively asses (Tłuchowski, Czapiński).

Approximately half of the discussed group proved to be proficient if not expert in the role of a commander of irregular military units. The rest did not meet the expectations or are difficult to evaluate objectively. As in the case of the majority of provenance groups the individual disposition was the decisive factor. Under other circumstances a several months long training would not yield results. Both commanders serving in the Austrian army who later attended to and graduated from the migratory institution, did not meet expectations although their potential in the discussed field should be above average.

It seems prudent to agree with Jan Moliński who was convinced that, first and foremost, the competent teaching cadre had undeniable influence on the education and training of the cadets and thanks to the efforts of the cadre a short but intensive course was sufficient for learning the general doctrines of combat and command of small units. Despite the fact that the course was devoted primarily to the subject of regular armed conflicts the acquired knowledge enabled skilled cadets to adequately command insurrectionist guerrilla units ${ }^{75}$.

\section{Theory and practice. Verification commander skills graduates of Polish Military School in Genoa and Cuneo (1861-1862) during the January Uprising (1863-1864) Summary}

In the run-up to independence uprising, from October 1861 to June 1862 thanks to permit the authorities of the United Kingdom of Italy and the intervention of Giuseppe Garibaldi functioned in Genoa and Cuneo Polish Military School was closed due to diplomatic pressure by the partitioning powers. Over the course of several months was the theoretical preparation of the January Uprising leadership cadre, and 15 graduates covered the self-command of the guerrilla armed parties. 4 of them belonged to the most prominent commanders for the entire war, also 4 can be regarded as promising. One showed just to be average, two were clearly weak. In two cases, it is difficult to set a clear assessment. For two commanders, former soldiers of the Austrian army were disappointing in the field. The Italic episode was an added element of military knowledge. The most significant was the individual's characteristics, although it certainly proved to be a useful body of knowledge transmitted by the emigration of well-prepared teachers cadet school.

Keywords: Polish Military School in Italy, Genoa, Cuneo, January Uprising commanders, theoretical preparation, commanding skills assessment in practice

About the author: dr Adam Bulawa, born 1971, assistant professor at Faculty of History and Social Sciences, Cardinal Stefan Wyszyński University in Warsaw - Department of Military History, Faculty of 19th and 20th Century History, Institute of History. Academic pursuits: 19th and 20th century history of Poland and the world, military history.

75 J. Moliński, Przygotowania do wybuchu powstania styczniowego, p. 97. 